\title{
Ten years of democracy: translating policy into practice in mathematics and science education
}

\author{
Kgabo Masehela \\ Human Sciences Research Council \\ Email: kmasehela@hsrc.ac.za
}

\section{Background}

This paper provides a 10-year (1994 - 2004) review of the state of mathematics and physical science education (SME) in South Africa with respect to participation and performance, and its relationship with policy implementation. The framework for this paper is guided by two broad questions:

- Which key policy initiatives were conceptualised, developed and disseminated in the last ten years?

- How has the system performed in respect to the participation and performance rate in mathematics and science education since 1994 ?

Through interviews, we also provide an overview of the voices of stakeholders (subject advisors, teachers and senior officials). The interviews were conducted in order to illuminate the challenges in translating policy to practice. Any adjudication of government policies in respect to physical science, mathematics and technology education (SMTE) should be read within the assumption that within ten years (1994-2004) there would have been less dramatic changes in the performance of what was one of the most divided education systems in the world.

In this paper, the ten-year period is divided into two periods, $1994-1999$, and $1999-2004$. The period between 1994 - 1999 is described by policy analysts as the policy formulation era. This is a period that was marked by the establishment of a unified, democratic and accountable system of government. The second period (1999 - 2004), described as the policy implementation era, is marked by dissemination of government policies.

\section{The era of policy design and development 1994 - 1999}

South Africa has produced formal policies and legislation as part of education reform. These include: White Papers (DoE 1995), National Education Policy Act (DoE, 1996a), South African Schools Act and National Norms and Standards for School Funding (DoE, 1996b), Employment of
Educator Act (RSA, 1998), Language Policy and Admission Policy (1996), as well as the Human Resource Development Strategy (DoL, 2001b). The Reconstruction and Development Programme (RDP) document laid a firm foundation for the design of all these policies. Its goals with respect to SME were:

- An appropriate mathematics, science and technology education that is essential to stem the waste of talent.

- Rewriting the schooling curriculum and raising the quality of learning and teaching through in-service education of teachers (INSET) and upgrading the professional competence of teachers.

Following the RDP document, the White Paper on Education and Training (DoE, 1995) outlined 'the most direct way' of redressing the imbalances of the past around issues of SME. These papers indicated that special initiatives were needed to prepare learners for subjects in short supply and noted the following,

- Only one in five black learners choose physical science and mathematics in standard 8 (grade 10), and the trend of performance in the senior certificate examinations has been low overall, with a particularly dismal matriculation exemption rate among learners taking these subjects at higher grade.

- Fewer black learners with science and mathematics qualify for normal entry to higher education.

South African policies aim to bring equity and redress in education. However, under South African contextual conditions and reality, to what extent could these policies be implemented? Are there some doubts whether these policies are achieving their intended objectives? Have these policies increased the participation and performance rate in mathematics and science? To what extend have they increased? This will be revisited later in the paper. 


\section{The era of policy implementation 1999 - 2004}

\section{Curriculum innovations and development}

The introduction of Curriculum 2005 in February 1997 marked a major school reform initiative in education. This new curriculum, based on a constructivist epistemology, initiates learners into what Stenhouse (1976) calls 'worthwhile activities' ranging from hands-on activities, group discussions, project work, etc. While the conceptual design of C2005 seemed plausible, the implementation proved to be a challenging exercise. The first problem in implementation was the failure to estimate the extent to which resources would be a constraining factor. The second shortcoming was the impracticality of providing in-service training to all teachers in the General Education and Training (GET) phase of schooling. A review of the curriculum acknowledged deficiencies in design and content. This resulted in a streamlined curriculum in terms of learning areas that also reduced use of complicated terminology. In a sense, the Revised National Curriculum Statements (RNCS) overcame the fundamental flaws of C2005.

\section{Human Resource Development Strategy}

Initiatives in mathematics and science were initially set out by the RDP document and White Paper on Education and Training (1995). South Africa's president reiterated the centrality of these subjects in two State of the Nation addresses (2000 and 2001). Following this, the ministers of labour and education jointly launched the Human Resource Development (HRD) Strategy for South Africa in June 2001. A practical initiative coming from the strategy was the creation of the 102 Dinaledi Schools ('Creating Tomorrow's Stars'), established as an attempt to increase the participation rate. In line with the redress agenda, resources were concentrated on a set of schools rather than all the schools - that would become quality sites of science and mathematics teaching (Kahn, 2003).

The HRD Strategy, which also has its origins in the RDP, is an attempt to operationalise President Mbeki's ideas made in his 2000 and 2001 State of the Nation addresses. In terms of the HRD Strategy Indicator Five: Mathematics and Science Results (DoL, 2001b: 25) 'the problem in mathematics and science has not to do with numbers who passed on higher grade or who obtained university exemptions'. The strategy notes that 'generally, mathematical and science literacy are extremely poor in the entire schooling system'.
In order to arrest the chronic situation the former minister of education, Prof. Kader Asmal, tasked his deputy minister, Mr. Mosibudi Mangena, with a clear utilitarian prescription amongst others - to increase the rate of participation of black learners, especially females. Following the Department of Education's strategy to improve mathematics and science, the deputy minister released the names of 102 dedicated mathematics and science high schools as part of a national strategy to improve mathematics and science in schools (Bot and Masehela, 2003).

Provincial departments were requested to draw their own strategic plans for mathematics, science and technology education for the next six years (2003 - 2008). The provincial plans had to include their vision, mission and commitment to restructuring GET and Further Education and Training (FET) in terms of professional development, provision of resources, new curriculum implementation, delivery, administrative and community support. All these had to be designed in line with the national HRD Strategy for mathematics and science.

The Department of Education earmarked more than R400-million for the promotion of science and mathematics (Mega boost for maths and science, 2001). This financial injection allowed the project to supply schools with resources such as books, satellite television and laboratory equipment, and mathematics and science educators were offered special training sessions.

An audit of the 102 Dinaledi Project Schools indicates that from a total of 307 mathematics and science teachers, 188 (64.6\%) have obtained a grade 12 qualification and 177 (56.7\%) a diploma as a professional qualification. A few teachers have obtained honours (17, or 5.6\%) and the Eastern Cape has the highest number of educators (5) with masters degrees. It is in the light of this background that we can see the growing demand being made on teachers and learners for significant change in the teaching and learning of mathematics, science and technology.

\section{Participation and performance rate}

It is now critical to take stock of how these policies were translated into practice in terms of participation, performance and quality higher grade (HG) passes by examining trends since 1996. Participation in this paper refers to learners enrolling for matric while performance refers to the quality of passes, particularly in HG.

South Africa has in the last years witnessed a drop in the number of grade 12 candidates. Table 1 
Table 1. Enrolment trends and Pass and Failure Rate 1996 - 2003.

\begin{tabular}{|c|c|c|c|c|}
\hline Year & $\begin{array}{c}\text { Candidates } \\
(\mathbf{N})\end{array}$ & $\begin{array}{c}\text { \% increase } \boldsymbol{I} \\
\text { decrease }\end{array}$ & $\begin{array}{c}\text { Candidates passing } \\
(\%)\end{array}$ & $\begin{array}{c}\text { Candidates passing } \\
\text { with exemption (\%) }\end{array}$ \\
\hline 1996 & 518032 & & $278958(53.8)$ & 79768 \\
\hline 1997 & 556246 & 7.4 & $261400(47.0)$ & 69007 \\
\hline 1998 & 552384 & -0.4 & $273118(49.3)$ & 69891 \\
\hline 1999 & 511474 & -7.7 & $249831(48.8)$ & 63715 \\
\hline 2000 & 489941 & -4.2 & $283294(57.8)$ & 68626 \\
\hline 2001 & 449371 & -8.3 & $277206(61.7)$ & 67707 \\
\hline 2002 & 443821 & -1.2 & $305774(68.9)$ & 75048 \\
\hline 2003 & 440267 & -0.8 & $322492(73.3)$ & 82010 \\
\hline 2004 & 467985 & 6.3 & $330717(70.7)$ & 85117 \\
\hline
\end{tabular}

Sources: DoE 2004; Edusource DataNews 2001/2002

provides a picture of the enrolment trends since 1996.

Table 1 shows a decrease in enrolment data between 1996 and 2003. Although the number of candidates passing has been on the increase, it is worrying that the number of candidates enrolling for grade 12 has decreased significantly by approximately 80 000. According to Van der Berg (2004), to judge matriculation results in context we should not only look at those who write the matriculation examination, but also those who should have been in matric. If we consider the 18year-old or matric aged cohort in 2003, 985000 learners should have written the matric examination. Instead 440267 sat for the examination and 322492 passed. 58\% of African candidates do not reach matric, and only 5.2\% of African candidates achieved results that should have given them university entry. The decrease noted in the table is what Kozol (1996) calls the 'human wastage' and this is a challenge to South Africa. For example, 330717 passed the examination from a total of 467985 in 2004 and 137268 learners failed. Given this data, where do failing learners go? What is government doing to absorb these learners into formal employment? Will these learners be allowed to repeat if most of them are not over age? Will they enrol for Adult Basic Education and Training (ABET) programmes, or will they undertake supplementary examinations? These issues require further investigation.

Table 2 shows that the total enrolment of mathematics and science learners increased between 1996 and 2004 from 218225 to 276094 in mathematics and from 122278 to 161214 in physical science. The total number of candidates who passed mathematics also increased from 108910 in 1996 to 156795 in 2004. Similarly, physical science increased from 74110 to 119543. The increases in the matric pass rate between 2000 and 2004 has been linked to falling candidate numbers (cf. Table 1) and weaker candidates or 'at risk' grade 11 learners being filtered to grade 12 therefore leaving a pool of generally stronger candidates, a greater proportion of learners with the potential to pass (De Souza, 2003).

Of particular significance (cf. Table 2) is the fact that between 1997 and 2004, candidates writing mathematics HG dropped from 68451 to 39 939. Similarly, physical science had a drop from 76086 to 55 969. However, the overall pass rate increased as from 2000. In mathematics the pass rate rose from $45 \%$ in 2000 to $59 \%$ in 2003 while it rose from $69 \%$ to $80 \%$ in physical science.

With respect to standard grade (SG), on the other hand, the number of candidates who registered for mathematics and science increased especially in 2000 (cf. Table 3). 
Ten years of democracy: translating policy into practice in mathematics and science education

Table 2. Mathematics and Science participation and performance $1996-2004$.

\begin{tabular}{|c|c|c|c|c|c|c|c|c|}
\hline $\begin{array}{l}\text { Mathe- } \\
\text { matics } \\
\text { HG }\end{array}$ & Year & $\begin{array}{c}\text { Total } \\
\text { Enrolment }\end{array}$ & $\begin{array}{c}\text { Total } \\
\text { Passed } \\
\text { (SG/HG) }\end{array}$ & $\%$ Pass & Wrote HG & $\begin{array}{l}\text { Males } \\
\text { Passed }\end{array}$ & $\begin{array}{l}\text { Females } \\
\text { Passed }\end{array}$ & \begin{tabular}{|c|} 
Total \\
Passed \\
HG \\
candidates \\
\end{tabular} \\
\hline & 1996 & 218225 & 108910 & 49.9 & 65223 & 12817 & 9599 & 22416 \\
\hline & 1997 & 252617 & 116836 & 46.3 & 68451 & 12829 & 9969 & 22798 \\
\hline & 1998 & 298195 & 124005 & 41.6 & 63899 & 11579 & 9581 & 21160 \\
\hline & 1999 & 281304 & 122225 & 43.4 & 50105 & 10660 & 9194 & 19854 \\
\hline & 2000 & 284017 & 128142 & 45.1 & 38520 & 10207 & 9120 & 19327 \\
\hline & 2001 & 263945 & 123149 & 46.7 & 34870 & 10084 & 9420 & 19504 \\
\hline & 2002 & 260989 & 146446 & 56.1 & 35465 & 10804 & 9724 & 20528 \\
\hline & 2003 & 258323 & 151905 & 58.8 & 35956 & 12564 & 10848 & 23412 \\
\hline & 2004 & 276094 & 156795 & 56.8 & 39939 & 13325 & 10818 & 24143 \\
\hline $\begin{array}{c}\text { Physical } \\
\text { Science } \\
\text { HG }\end{array}$ & Year & $\begin{array}{c}\text { Total } \\
\text { Enrolment }\end{array}$ & $\begin{array}{c}\text { Total } \\
\text { Passed } \\
\text { (SG/HG) }\end{array}$ & $\%$ Pass & Wrote HG & $\begin{array}{l}\text { Males } \\
\text { Passed }\end{array}$ & $\begin{array}{l}\text { Females } \\
\text { Passed }\end{array}$ & \begin{tabular}{|c|} 
Total \\
Passed \\
HG \\
candidates \\
\end{tabular} \\
\hline & 1996 & 122278 & 74110 & 60.6 & 70269 & 15140 & 10322 & 25462 \\
\hline & 1997 & 141278 & 91538 & 64.8 & 76086 & 15925 & 11046 & 26971 \\
\hline & 1998 & 168632 & 108896 & 64.6 & 79019 & 16443 & 11651 & 28094 \\
\hline & 1999 & 160949 & 102896 & 63.9 & 66486 & 13818 & 10373 & 24191 \\
\hline & 2000 & 163185 & 112164 & 68.7 & 55699 & 13135 & 10209 & 23344 \\
\hline & 2001 & 153847 & 105552 & 68.6 & 48996 & 13609 & 10671 & 24280 \\
\hline & 2002 & 153855 & 117529 & 76.4 & 50992 & 13979 & 10909 & 24888 \\
\hline & 2003 & 151791 & 121947 & 80.3 & 52080 & 14935 & 11132 & 26067 \\
\hline & 2004 & 161214 & 119543 & 74.2 & 55969 & 15447 & 11528 & 26975 \\
\hline
\end{tabular}

Source: own calculations based on Department of Education 2004, SCE database

Table 3 indicates a decrease in the number of learners writing mathematics and science SG. As the number of learners writing mathematics increased from 149510 in 1996 to 236155 in 2004, the number of passes increased from 89896 to 109446 . Similarly, learners writing physical science increased from 52252 to 105245 and the passes increased from 30306 (58\%) to 78025 (74\%).

Due to structural changes brought about by formal economies changing, with less reliance on industries based on mining and agriculture to reliance on jobs in the financial sector, there is a need for candidates with quality higher grade passes in mathematics and science (National Skills Development Strategy, 2001). The National Strategy for Science, Mathematics and Technology
Education and the subsequent establishment of the 102 Focus Schools attempts to increase the number of HG passes and eventually respond to the question of supply and demand in the economic sector. If the declining trend of learners writing mathematics and science is not arrested, how will this affect the South African economy?

According to the National Skills Development Strategy (DoL, 2001a) high skilled jobs increased by 20\% between 1970 and 1998. The United Nations Development Programme (UNDP, 2001: 28 ) indicates that science and technology activities require a skilled workforce and human resources development is therefore important. The South African White Paper on Science and Technology (DACST, 1996), on the other hand, indicates that any national system of innovation requires an 
Table 3. Mathematics and Science HG/SG

\begin{tabular}{|c|c|c|c|c|c|}
\hline $\begin{array}{c}\text { Mathe- } \\
\text { matics }\end{array}$ & SG & Failed & Passed & Pass \% & $\begin{array}{c}\text { Pass over } \\
\text { previous year }\end{array}$ \\
\hline $\mathbf{1 9 9 6}$ & 149510 & 89896 & 59614 & $39.9 \%$ & \\
\hline $\mathbf{1 9 9 7}$ & 184166 & 98818 & 85348 & $46.3 \%$ & $43.17 \%$ \\
\hline $\mathbf{1 9 9 8}$ & 234296 & 140467 & 93829 & $40.1 \%$ & $9.94 \%$ \\
\hline $\mathbf{1 9 9 9}$ & 231199 & 136161 & 95038 & $41.1 \%$ & $1.29 \%$ \\
\hline $\mathbf{2 0 0 0}$ & 245497 & 142232 & 103265 & $42.1 \%$ & $8.66 \%$ \\
\hline $\mathbf{2 0 0 1}$ & 229075 & 131310 & 97765 & $42.7 \%$ & $-5.33 \%$ \\
\hline $\mathbf{2 0 0 2}$ & 225524 & 104593 & 120931 & $53.6 \%$ & $23.70 \%$ \\
\hline $\mathbf{2 0 0 3}$ & 222367 & 99155 & 123212 & $55.4 \%$ & $1.89 \%$ \\
\hline $\mathbf{2 0 0 4}$ & 236155 & 109446 & 126709 & $53.7 \%$ & $2.84 \%$ \\
\hline \multicolumn{7}{|l|}{} & & & \\
\hline $\begin{array}{c}\text { Physical } \\
\text { Science } \\
\text { HG }\end{array}$ & SG & Failed & Passed & Pass \% & Pass over \\
\hline $\mathbf{1 9 9 6}$ & 52252 & 21946 & 30306 & $58.0 \%$ & \\
\hline $\mathbf{1 9 9 7}$ & 65192 & 18610 & 46582 & $71.5 \%$ & $53.71 \%$ \\
\hline $\mathbf{1 9 9 8}$ & 89613 & 27188 & 62425 & $69.7 \%$ & $34.01 \%$ \\
\hline $\mathbf{1 9 9 9}$ & 94463 & 32095 & 62368 & $66.0 \%$ & $-0.09 \%$ \\
\hline $\mathbf{2 0 0 0}$ & 107486 & 31605 & 75881 & $70.6 \%$ & $21.67 \%$ \\
\hline $\mathbf{2 0 0 1}$ & 104851 & 34753 & 70098 & $66.9 \%$ & $-7.62 \%$ \\
\hline $\mathbf{2 0 0 2}$ & 102863 & 24244 & 78619 & $76.4 \%$ & $12.16 \%$ \\
\hline $\mathbf{2 0 0 3}$ & 99711 & 17768 & 81943 & $82.2 \%$ & $4.23 \%$ \\
\hline $\mathbf{2 0 0 4}$ & 105245 & 27220 & 78025 & $74.1 \%$ & $-4.78 \%$ \\
\hline
\end{tabular}

Source: own calculations based on Department of Education 2004, SCE database

enabling framework for socio-economic development in the country. The figures as illustrated in the tables are a challenge to the attainment of the white paper's enabling framework. This is because, despite substantial increments in school resources and a more equitable allocation of resources in mathematics and science, the overall output of candidates has not kept pace with the input. If the above policy pronouncements are not fulfilled, there is a need for structural reconfigurations. Implementation of these reconfigurations and changes will also require urgent attention.

\section{Performance by province}

Table 4 provides provincial data in terms of participation and performance trends in mathematics and science between 1996 and 2004. With the exception of North West, all provinces experienced an increase in the number of candidates passing the matric examination. The table shows that the number of learners passing with endorsement has on average largely remained the same in many provinces. Gauteng and Limpopo experienced a significant increase in the number of endorsements between 1996 and 2004 and, on the contrary, Eastern Cape and North West experienced a decrease.

Gauteng, Kwazulu Natal, Limpopo, Mpumalanga and North West experienced a drop in the number of learners enrolling for mathematics HG. Similarly, with the exception of Free State, all provinces experienced an increase in learners enrolling for science $\mathrm{HG}$.

Given the data in Table 4, 'what is the performance of African candidates in senior certificate examinations for mathematics and physical science?' Table 5 presents provincial results using the Language Proxy Method (Kahn, 2003). Kahn (ibid.) provides data (Table 5) for a number of African learners who passed with mathematics HG. These results respond to questions raised in parliament in 2000 namely, is it true that only 3000 African learners obtain a mathematics $H G$ pass? Kahn (ibid.) provides an analysis of provincial results using what he terms 
Ten years of democracy: translating policy into practice in mathematics and science education

Table 4: Performance by Province.

\begin{tabular}{|c|c|c|c|c|c|c|c|c|c|c|}
\hline Dept & Yr & $\begin{array}{l}\text { Candidates } \\
\text { who wrote }\end{array}$ & $\begin{array}{c}\text { Candidates } \\
\text { who } \\
\text { passed }\end{array}$ & $\begin{array}{l}\text { Candidates } \\
\text { who gained } \\
\text { endorsement }\end{array}$ & M Cand & M HG & $\begin{array}{l}\text { M HG } \\
\text { Pass }\end{array}$ & S Cand & $\begin{array}{l}\text { S HG } \\
\text { Cand }\end{array}$ & $\begin{array}{l}\text { S HG } \\
\text { Pass }\end{array}$ \\
\hline \multirow{3}{*}{$\begin{array}{c}\text { Eastern } \\
\text { Cape }\end{array}$} & 1996 & 66809 & 32639 & 7061 & 24567 & 3118 & 1031 & 15402 & 6249 & 1552 \\
\hline & 2000 & 74563 & 37118 & 5332 & 42747 & 1440 & 1085 & 25989 & 2251 & 993 \\
\hline & 2004 & 63426 & 33915 & 5564 & 39958 & 2392 & 1535 & 23941 & 2431 & 1487 \\
\hline \multirow{3}{*}{$\begin{array}{l}\text { Free } \\
\text { State }\end{array}$} & 1996 & 35554 & 18153 & 4208 & 15050 & 2761 & 1165 & 9400 & 3939 & 1811 \\
\hline & 2000 & 29477 & 15538 & 3697 & 16888 & 1685 & 1109 & 10305 & 3799 & 2149 \\
\hline & 2004 & 24731 & 19459 & 5480 & 12423 & 1768 & 1346 & 7937 & 2960 & 1681 \\
\hline \multirow[b]{3}{*}{ Gauteng } & 1996 & 72959 & 42142 & 13810 & 38635 & 11355 & 5932 & 25298 & 13692 & 7010 \\
\hline & 2000 & 68202 & 46056 & 12896 & 44799 & 7332 & 5577 & 28964 & 8835 & 6180 \\
\hline & 2004 & 71382 & 54808 & 15780 & 44821 & 9062 & 6710 & 28660 & 10852 & 6889 \\
\hline \multirow{3}{*}{$\begin{array}{c}\text { KwaZulul } \\
\text { Natal }\end{array}$} & 1996 & 86608 & 53397 & 20040 & 40832 & 16677 & 6978 & 19613 & 13261 & 6186 \\
\hline & 2000 & 96423 & 55128 & 15655 & 64075 & 11325 & 4709 & 32775 & 13208 & 5869 \\
\hline & 2004 & 110635 & 81830 & 20950 & 74932 & 9230 & 5356 & 39051 & 13516 & 6221 \\
\hline \multirow[b]{3}{*}{ Limpopo } & 1996 & 126081 & 47569 & 9351 & 40800 & 18505 & 1517 & 20069 & 15942 & 2202 \\
\hline & 2000 & 95191 & 48886 & 11100 & 46651 & 8389 & 1452 & 24719 & 13592 & 2041 \\
\hline & 2004 & 77774 & 54897 & 16273 & 39228 & 7647 & 2046 & 21733 & 13757 & 3337 \\
\hline \multirow{3}{*}{$\begin{array}{c}\text { Mpuma- } \\
\text { langa }\end{array}$} & 1996 & 41731 & 19739 & 4332 & 15654 & 4534 & 1220 & 9947 & 5855 & 1194 \\
\hline & 2000 & 41115 & 21694 & 4762 & 21369 & 2446 & 894 & 13342 & 4866 & 1207 \\
\hline & 2004 & 37091 & 22913 & 4640 & 19334 & 2186 & 1283 & 13159 & 3809 & 1436 \\
\hline \multirow{3}{*}{$\begin{array}{l}\text { North } \\
\text { West }\end{array}$} & 1996 & 46349 & 32185 & 7611 & 18272 & 4466 & 1430 & 10727 & 6453 & 1982 \\
\hline & 2000 & 40098 & 23366 & 5057 & 22595 & 1880 & 1041 & 13220 & 4886 & 1200 \\
\hline & 2004 & 37327 & 24221 & 4647 & 20822 & 1853 & 1314 & 12993 & 3255 & 1601 \\
\hline \multirow[b]{3}{*}{ N Cape } & 1996 & 7111 & 5194 & 1225 & 2606 & 484 & 279 & 1574 & 511 & 333 \\
\hline & 2000 & 7054 & 5019 & 892 & 2910 & 330 & 298 & 1705 & 354 & 256 \\
\hline & 2004 & 6723 & 5609 & 1259 & 2767 & 459 & 382 & 1616 & 505 & 386 \\
\hline \multirow{3}{*}{$\begin{array}{c}\text { Western } \\
\text { Cape }\end{array}$} & 1996 & 34830 & 17940 & 12130 & 18317 & 3323 & 2864 & 10491 & 3958 & 3192 \\
\hline & 2000 & 37818 & 30489 & 9235 & 21983 & 3693 & 3162 & 12168 & 3910 & 3449 \\
\hline & 2004 & 38896 & 33065 & 10524 & 22023 & 5093 & 4268 & 12124 & 4884 & 3937 \\
\hline
\end{tabular}

Source: Own calculations from Department of Education 1996, 2001, 2004 Reports

the Language Proxy Method that he developed to identify African candidates taking mathematics and science. Such candidates were identified only by their having taken an African language among their Senior Certificate examination subjects. There might have been African candidates who did not study an African language, but it was argued that they could not number more than 5\%.

Following the proxy method, Table 5 provides the disaggregated data by province in 2002. It may be observed from the table that Limpopo had the highest number of learners taking mathematics and science compared with Gauteng and Western Cape, for example, because proportionally Limpopo has the highest African population of these provinces. The results presented here respond to the questions raised in parliament in 2000 .

\section{Performance by Gender}

The Education White Paper 2 (1995) recommends that females take these subjects (mathematics and science), which are critical for the further development and growth of our nation. It proposes 'to increase the number of girls in science streams' through the equitable-school based funding formula. The period 1996 - 2002 has seen the female performance in mathematics improving substantially, with both the number of female candidates participating growing at a faster rate than male candidates and the gender gap in pass rates decreasing. The percentage of female candidates passing higher grade mathematics was higher in 2002 than that of male candidates. 
Table 5: Performance by Province (following the proxy method).

\begin{tabular}{|c|r|r|r|r|r|r|r|r|}
\hline & \multicolumn{2}{|c|}{ Math HG } & \multicolumn{2}{c|}{ Math SG } & \multicolumn{2}{c|}{ Phys Sci HG } & \multicolumn{2}{c|}{ Phy Sci SG } \\
\hline $\mathbf{2 0 0 2}$ & Proxy & \multicolumn{1}{|c|}{ Entry } & Proxy & \multicolumn{1}{|c|}{ Entry } & Proxy & Entry & Proxy & Entry \\
\hline WC & 172 & 246 & 3865 & 5189 & 207 & 285 & 1975 & 2782 \\
\hline NC & 28 & 57 & 424 & 688 & 22 & 45 & 263 & 397 \\
\hline FS & 380 & 493 & 9758 & 10137 & 1607 & 1736 & 4836 & 6393 \\
\hline EC & 599 & 833 & 33131 & 34674 & 704 & 972 & 19608 & 20471 \\
\hline KZN & 4560 & 5029 & 45724 & 48159 & 6838 & 7332 & 19147 & 19670 \\
\hline MP & 861 & 999 & 15537 & 16445 & 2487 & 2703 & 8199 & 8757 \\
\hline LP & 5546 & 5779 & 27670 & 28266 & 10784 & 11101 & 7744 & 8003 \\
\hline GP & 1568 & 2451 & 17876 & 22972 & 2339 & 3498 & 9385 & 12276 \\
\hline NW & 731 & 832 & 16686 & 17054 & 2212 & 2358 & 8017 & 8244 \\
\hline Totals & $\mathbf{1 4 4 4 5}$ & $\mathbf{1 6 7 1 9}$ & $\mathbf{1 7 0 6 7 1}$ & $\mathbf{1 8 3 5 8 4}$ & $\mathbf{2 7 2 0 0}$ & $\mathbf{3 0 0 3 0}$ & $\mathbf{7 9 1 7 4}$ & $\mathbf{8 6 9 9 3}$ \\
\hline
\end{tabular}

Source: Kahn 2003

Table 6 shows that the number of female candidates that enrol for mathematics is higher than those of males. In fact the number of females is much higher than the number of males in SG mathematics. However, as is shown in Table 2, the male pass rate in both mathematics and physical science HG has become increasingly higher than that of females between 1996 and 2002. According to Van der Berg (2004) and Perry (2003), 13.7\% of females, as opposed to $10 \%$ of their male counterparts, failed the 2003 matric examinations.
The above trend suggests that there are more females participating in mathematics and science, and whether these females come from African schools or former Model C schools is a point that requires further research. It could be discerned from that the above data that if mathematics and science are about participation and performance, males will continue to have access to power, as they will enrol at tertiary institutions in fields such as engineering. And males will resultantly occupy positions and benefits that come with the subjects.

Table 6: Number of Mathematics Candidates and Passes, Average Annual Growth and Pass Rates by Gender, 1996 and 2002.

\begin{tabular}{|c|c|c|c|c|c|c|}
\hline Subject & Gender & 1996 & 2002 & $\begin{array}{c}\text { Average } \\
\text { annual \% } \\
\text { growth }\end{array}$ & $\begin{array}{l}\text { Pass } \\
\text { rate } \\
1996\end{array}$ & $\begin{array}{l}\text { Pass } \\
\text { rate } \\
2002\end{array}$ \\
\hline \multirow[b]{2}{*}{ Maths candidates } & Male & 103056 & 122902 & $3.0 \%$ & & \\
\hline & Female & 111677 & 138087 & $3.6 \%$ & & \\
\hline \multirow[b]{2}{*}{ Maths passes } & Male & 48701 & 63299 & $4.5 \%$ & $47.30 \%$ & $51.50 \%$ \\
\hline & Female & 42625 & 58518 & $5.4 \%$ & $38.20 \%$ & $42.40 \%$ \\
\hline \multirow[b]{2}{*}{ Maths HG candidates } & Male & 34577 & 18867 & $-9.6 \%$ & & \\
\hline & Female & 30646 & 16598 & $-9.7 \%$ & & \\
\hline \multirow[b]{2}{*}{ Maths HG passes } & Male & 12817 & 10804 & $-2.8 \%$ & $37.10 \%$ & $57.30 \%$ \\
\hline & Female & 9599 & 9724 & $0.2 \%$ & $31.30 \%$ & $58.60 \%$ \\
\hline \multirow[b]{2}{*}{ Maths HG conversion SG } & Male & 5497 & 2831 & $-10.5 \%$ & & \\
\hline & Female & 3799 & 2156 & $-9.0 \%$ & & \\
\hline \multirow[b]{2}{*}{ Maths SG candidates } & Male & 68479 & 104035 & $7.2 \%$ & & \\
\hline & Female & 81031 & 121489 & $7.0 \%$ & & \\
\hline \multirow[b]{2}{*}{ Maths SG passes } & Male & 30387 & 49664 & $8.5 \%$ & $44.40 \%$ & $47.70 \%$ \\
\hline & Female & 29227 & 46638 & $8.1 \%$ & $36.10 \%$ & $38.40 \%$ \\
\hline
\end{tabular}

Source: EduSource 2002 


\section{Translating policy to practice: the voices of teachers, subject advisors and senior officials}

The last section of this paper illuminates the impediments towards increasing the participation and performance rate in mathematics and science. Subject advisors and district officials from Gauteng were interviewed following MeulenbergBuskens' Free Attitude Interview Technique (1997). The technique involves asking one question to the interviewees in a focus group and then allowing respondents to unpack, debate, discuss, and (dis)agree on why South Africa is unable to increase the participation rate of black, and in particular female students. As the interviewer, I merely asked clarifying questions to keep the conversation on track and at various phases of the interviews provided a reflective summary to focus their minds on the main question. Telephonic interviews were also conducted with mathematics and science educators from Free State and Limpopo. The input from this group of educators was solicited because of their contact with the reality of the situation on the ground.

Five key themes emerged from an analysis of the interview data. These were:

- Resourcing - The environment at school level is not conducive to increasing the participation rate, and township schools especially lack resources. To this effect a typical response was 'there is a lack of media centres, laboratories, and current, relevant books in schools'.

- Support of teachers at the classroom level - Learning Area Specialists have to undertake regular classroom visits to support teachers in planning their lessons and teaching process. However, as data from the interview indicates, there is little support from Learning Area Specialists at District Level because 'districts are understaffed, under qualified, or have people with no qualifications at all.

- Qualifications - Learning Area Specialists and teachers (including primary school teachers) have to improve their qualifications in order to increase the performance rate in mathematics and science. District officials are increasingly faced with new developments, including the implementation of the Revised National Curriculum Statement (RNCS), and are therefore not able to deal with the professional demands at hand.
- Discouraging learners to continue with the subject - As prescribed by the Mathematical Literacy, Mathematics and Mathematical Sciences (MLMMS) requirements, teachers confirm that 'learners cannot be encouraged to enrol for mathematics in grade 10, especially if they have failed (obtained less than $33.3 \%$ ) grade 9'. Secondly, teachers discourage learners from taking mathematics and science from grade 11 onwards if they have obtained less than $40 \%$ at $\mathrm{HG}$ in grade 10 . 'If learners obtain between $33.3 \%$ and $40 \%$, they can still study at SG'. According to district officials 'teachers are worried that a school's performance will drop' and eventually affect the 'school image'. There is, therefore, a tight selection of learners, and this eventually contributes to learners' repetition of the same grade, to eventually dropping out (cf. Table 1).

- Intervention Programmes - There are a number of mathematics and science intervention programmes that have been implemented, and as district officials indicate 'an impact evaluation study is yet to take place'. For example, 'Saturday classes require learners to perform at a certain level, and lessons are often taught at a higher level'. There is, therefore, a mismatch between intervention programmes and the cognitive level of learners attending the programmes. Furthermore, 'there is no remedial programme in place to support learners in need of individual attention, especially learners in overcrowded classrooms'. ${ }^{1}$

\section{Conclusion}

This paper has outlined key policy and legislative initiatives designed and implemented during the two ministerial terms of $1994-1999$ and 1999 2004. This paper has attempted to examine the extent to which these policies have been translated into practice with respect to increasing the participation and performance rate in mathematics and science. Although the policy encourages learners to enrol for mathematics and science HG,

1 The recommended number of learners per class at secondary school is 35 (SASA, 1996), but many township classes have an average of 46. 
data indicates that the majority of learners enrol for these subjects at SG level. For example, 30086 learners passed mathematics HG and 126709 passed at SG in 2004. This reflects a number of issues, amongst them are:

- A lack of confidence in the quality of mathematics and science education by both education administrators and policy makers. The system is not ready in terms of teacher qualifications and resources to enrol more learners in HG and learners are not confident of passing at this grade level.

- Misinterpretation of policies at school level by pushing more learners into SG.

- Policies have as yet not filtered down to classroom levels hence learners increasingly take these subjects at SG.

Although the government laid the groundwork for improvements in the education system in terms of policies, the number of learners passing mathematics and science higher grade has not increased. It could be deduced that results in the first ten years of democracy have not been gratifying. However, it may be too soon to make a judgment compared to what was produced before 1994. However, there is a need to set some shortterm goals by considering targets on year-to-year increments.

The analysis appears to show that while a lot has been done in terms of policy designs and implementation, a lot more remains unachieved. However, an understanding is slowly but surely emerging that policies have been taken seriously and will yield better results in the near future. For now we may feel dissatisfied with the numbers but the context and where we come from should be important. Following Jansen and Sayed's (2001) argument, it is plausible to study these policies in the context of the government having laid the groundwork for long-term and sustainable improvements in education. Finally, the Dinaledi schools project presents just one case of government initiative in terms of operationalising government policies with respect to the HRD Strategy. We recommend that these schools should not be pressurised to produce immediate results. In as much as it takes time for a plant to grow, it takes time for policies to produce immediate results.

\section{References}

BOT, M. \& MASEHELA, K., 2003, "Provincialisation of Education, a Review. July
2001 - December 2002”, EduSource DataNews 41, pp 11-37

CARRIM, N., 2001, "Democratic participation and education reform”, in Jansen, J. \& Sayed, Y., eds., Implementing education policies, the South African Experience, Cape Town: University of Cape Town Press

DACST (Department of Arts, Culture, Science \& Technology), 1996, South African White Paper on Science and Technology, Pretoria

DoE (DEPARTMENT OF EDUCATION), 1995, White Paper on Education and Training, Pretoria

DoE (DEPARTMENT OF EDUCATION), 1996a, "National Education Policy Act", Government Gazette 370

DoE (DEPARTMENT OF EDUCATION), 1996b, "South African Schools Act", Government Gazette 377

DoE (DEPARTMENT OF EDUCATION), 1997, "Language Policy and Admission Policy" Government Notice, 383

DoE (DEPARTMENT OF EDUCATION), 2001, National Strategy for Improving Science, Mathematics and Technology Education, Pretoria

DoL (DEPARTMENT OF LABOUR), 2001a, National Skills Development Strategy, Pretoria

DoL (DEPARTMENT OF LABOUR), 2001b, Human Resource Development Strategy Indicator Five: Mathematics and Science Results, Pretoria

DE SOUZA, C., 2003, "Senior certificate exams 2002: Plausible progress or passes below par?" EduSource DataNews 39, pp 1-13

JANSEN, J. \& SAYED, Y., 2001, Implementing education policies, The South African Experience, Cape Town: UCT Press

KAHN, M., 2003, "For whom the school bell tolls: disparities in performance in Senior Certificate Mathematics and Physical Science”, Perspectives in Education 30, 4, pp 149-156

KOZOL, J., 1996, Savage Inequalities. Children in America's schools. New York: Harper Perennial

MEGA BOOST FOR MATHS AND SCIENCE, 2001, August 24, The Star, p 7

MEULENBERG-BUSKENS, I., 1997, "Free Attitude Interview Technique", Research for the Future, pp 1-6. Unpublished workshop manual, Vista University

PERRY, H., 2003, "Female performance in the senior certificate examination: excellence hiding behind the averages”, EduSource DataNews 39, pp 14-27 
Ten years of democracy: translating policy into practice in mathematics and science education

STENHOUSE, L., 1976, An introduction to curriculum research and development, London: Heineman

UNDP (UNITED NATIONS DEVELOPMENT PROGRAMME), 2001, United Nations Development Programme

VAN DER BERG, S., 2004, Institute for Justice and Reconciliation Economic Transformation Audit 2004: Taking Power in the Economy. Retrieved May 26, 2005 from URL: http://www.capacitors.co.za/ta/ta/fullacademica rticles/fullacademicarticles/Education.The\%20c risis\%20in\%20schooling.Van\%20der\%20Berg. IJRTA\%20Chapter\%202\%202004.pdf

\section{Pointless Quest}

A needle in a haystack may be difficult to find.

Your chance of ever finding one is small

Especially with haystacks

of the ordinary kind, which don't have any needles in at all.

Piet Hein 